Médiation du discours expert : approches

linguistiques

\title{
Linguistic mediation of climate change discourse
}

\section{Kjersti Fløttum}

\section{(2) OpenEdition}

\section{Journals}

\section{Édition électronique}

URL : http://journals.openedition.org/asp/4182

DOI : 10.4000/asp.4182

ISSN : 2108-6354

Éditeur

Groupe d'étude et de recherche en anglais de spécialité

\section{Édition imprimée}

Date de publication : 1 mars 2014

Pagination : 7-20

ISSN : 1246-8185

\section{Référence électronique}

Kjersti Fløttum, «Linguistic mediation of climate change discourse », ASp [En ligne], 65 | 2014, mis en ligne le 15 mars 2015, consulté le 02 novembre 2020. URL : http://journals.openedition.org/asp/4182 ; DOI : https://doi.org/10.4000/asp.4182

Ce document a été généré automatiquement le 2 novembre 2020.

Tous droits réservés 


\title{
Linguistic mediation of climate change discourse
}

\author{
Kjersti Fløttum
}

\section{Introduction}

1 Why take a linguistic interest in the challenge of climate change? It is in fact one of the most pressing issues facing humanity today, and we experience a multitude of different opinions and attitudes to the question - from the so-called deniers to the believers (Zaccai et al. 2012). Climate change has moved from being predominantly a physical phenomenon to being simultaneously social, political, ethical, cultural and communicational (Hulme 2009, 2013; see also Giddens 2009; Malone 2009). Thus, there are obvious reasons for linguistics as well as other disciplines within the humanities to take an interest in the phenomenon:

Since 1988, science, politics, culture and ethics have exerted changing influences on the idea of climate change. The ways in which climate change is deployed in public life have diversified and proliferated. (Hulme 2013:1)

2 Furthermore, we know that the meaning people ascribe to climate change is closely related to how the phenomenon is portrayed in communication. In addition, previous research of the public's understanding of climate, climate-related concepts and research into risk communication have shown that even when scientists define complex concepts, often related to uncertainty, and explain implications, the public interprets them from their general knowledge of the language and the world (e.g. Leiserowitz 2007; Leiss 2004, Patt \& Schrag 2003; Weingart et al. 2000). This may lead to misinterpretations of various kinds. The climate debate becomes particularly complex and multifaceted, causing a range of communication challenges, due to the high number of stakeholders and the multitude of voices and opinions. In this, language plays a crucial role; the importance of linguistic and discursive approaches is obvious (Nerlich et al. 2010). Thus, the aim of the present analyses is to contribute to an improved understanding of the mediation of climate change discourse and of the role of language in this issue. 
In the rest of this paper, I will discuss a selection of linguistic and discursive features used in texts about climate change. In the first part (section 2), I will focus on expressions of uncertainty and the manifestation of voices, based on a document produced by the IPCC (Intergovernmental Panel on Climate Change). In the second part (section 3), I will adopt a textual-discursive perspective, arguing that the notion of narrative may contribute to a better understanding of the multiple "stories" which are constructed about the issue. Here my analyses will be based on different materials, mostly of political nature. In my final remarks (section 4), I will wrap up and consider the relevance of interdisciplinary collaboration in the study of climate change discourse.

\section{Analysis of the IPCC Summary for policymakers (2007)}

\subsection{General characteristics and related research questions}

4 The Summary for Policymakers is part of the Synthesis Report of the 4th Assessment Report published in 2007 by the Intergovernmental Panel on Climate Change - the IPCC, representing the most important scientific actors in the climate debate. The aim of the panel is to provide "a clear scientific view on the current state of knowledge in climate change and its potential environmental and socio-economic impacts", at the same time aiming "to reflect a range of views", in a manner which is "policy-relevant and yet policy-neutral, never policy-prescriptive" (<www.ipcc.ch/organization/ organization.shtml>). ${ }^{1}$ The Summary, which represents the most condensed message of current understanding of scientific, technical and socio-economic aspects of climate change, is addressed primarily to policymakers. In this respect, the text represents an important link between science and politics in the climate debate. In addition, the text is adapted to a non-scientific audience, through different explanatory comments, definitions and glossaries. Here I focus on the body text of the 22-page Summary. For reasons of space, tables, figures, illustrations and footnotes are not included in the analysis. This body text consists of sentences extracted verbatim from the Synthesis Report as well as condensed information from several statements.

In my analyses, I focus primarily on the aspects of uncertainty and complexity, inherent traits of climate knowledge, through questions related to the status of the claims which have been selected for inclusion in the Summary (see also Fløttum 2010; Fløttum \& Dahl 2011). Further, since this text represents a very condensed form of current knowledge, a relevant question is to what extent there are claims which can be posited with a high degree of confidence. Are there also "less certain" claims? Since the IPCC should "reflect a range of views" (see above), it is further relevant to investigate to what extent different voices are manifested, and whether any possible disagreement is expressed. I will also briefly consider whether there may be any traces of position taking, given that the IPCC summary should be policy neutral.

\subsection{Linguistic representations of uncertainty}

6 To handle and describe uncertainty in a uniform way by all the contributors to the IPCC report, the Panel has used mainly three approaches - two quantitatively based 
taxonomies and one qualitative taxonomy of pre-defined scalar expressions. Here are some examples of the quantitative approaches:

LIKELIHOOD OF OCCURRENCE, with labels of an 8-step scale from virtually certain ( $>99 \%)$ to exceptionally unlikely $(<1 \%)$ :

(1) Average Northern Hemisphere temperatures during the second half of the 20th century were very likely higher than during any other 50-year period in the last 500 years and likely the highest in at least the past 1300 years. (p. 2)

CONFIDENCE LEVEL, with a 5-step confidence interval scale, expressing the confidence in the correctness of a result: from very high to very low confidence:

(2) There is high confidence that neither adaptation nor mitigation alone can avoid all climate change impacts; however, they can complement each other and together can significantly reduce the risks of climate change. (p. 18)

There have been various kinds of criticism of this standardised language used to describe causes, impacts and risk (Budescu et al. 2009; Leiss 2004; Patt \& Schrag 2003). Patt \& Schrag (2003: 18) claim that laypersons' subjective understanding of probabilities depends on contextual factors, such as the magnitude of the described event. For instance, while the probability of relatively infrequent events is overestimated, the probability of relatively frequent events may be underestimated in lay audiences. And through various psychological experiments it has been showed that these terms may lead to confusion.

In my opinion there is another factor which should be considered: the fact that adverbs like likely are words that are frequent in ordinary language use. Thus, what does it mean when we say that something is likely to happen? The answer could go in different directions.

9 The third scale (primarily used in the IPCC Working Group III) is a qualitative twodimensional, 3-step level-of-understanding scale expressing agreement and evidence. The level of agreement in the literature on a particular finding was ranged, from high to low agreement. This was combined with a ranging of the amount of evidence, from much to limited evidence. Examples (3) and (4) illustrate this approach:

AGREEMENT AND EVIDENCE

(3) There is high agreement and much evidence that all stabilisation levels assessed can be achieved by deployment of a portfolio of technologies that are either currently available or expected to be commercialised in coming decades, [...]. (p. 20) (4) There is high agreement and medium evidence that Annex I countries' actions may affect the global economy and global emissions, although the scale of carbon leakage remains uncertain. (p. 18)

10 In a quantitative analysis of the scalar distribution and number of occurrences of the statements which are presented by means of the three taxonomies in the Summary, we found that nearly all the assessed claims belong in the high end of the scales. It is either very likely or likely that the mentioned outcomes have taken place or will take place; the degree of confidence is typically given as high; and the claims assessed qualitatively are mainly those where there is high agreement and much evidence (for details, see Fløttum \& Dahl 2011). From this we may conclude that the statements in the Summary clearly orient the discourse towards consensus; the IPCC authors point their non-scientific audiences in the direction of high-confidence and high-agreement claims.

11 Our analysis thus leads us to the question about the presence of diverging views and traces of other voices than the collective consensual IPCC voice, which will be the focus in the next section. However, before this shift of focus, I will give a few comments on 
the policy aspect of the Summary. The mandate of the IPCC is to be policy relevant and neutral, but not policy prescriptive. Here is an example:

(5) Societies have a long record of managing the impacts of weather-and climaterelated events. Nevertheless, additional adaptation measures will be required to reduce the adverse impacts of projected climate change and variability, regardless of the scale of mitigation undertaken over the next two to three decades. (p. 14)

The use of the contrastive connective nevertheless and the verb require in this example indicates that measures so far implemented are not adequate. There is thus here an underlying criticism of current policies. However, it is also clear that there is no proposed specific (political) action. Other examples may indicate consequences of not acting, as in the following:

(6) Delayed emission reductions significantly constrain the opportunities to achieve lower stabilisation levels and increase the risk of more severe climate change impacts. (p. 19)

13 However, in general, further analyses revealed that the IPCC remains policy neutral, even though there are relatively many linguistic traces of argumentation and discussion between different points of view as we will see in the next section.

\subsection{Representation of voices (polyphony)}

14 We know that the climate debate in general is particularly multi-voiced or polyphonic, and there are many important questions related to the voices participating in this debate, at different levels and in different contexts: Which voices are present, explicitly or implicitly, which ones are dominating, and which voices are absent (Fløttum 2010)? In order to understand what is at stake, for scientists as well as for non-scientists, it is important to know who says or believes what. What is of key interest in the present study is to what extent different points of view within the scientific community are expressed in the Summary. It might be a dilemma for the IPCC to "reflect a range of views" (as stated on their website; see above) and at the same time present a consensus view.

15 The Summary represents the formally agreed statement of the IPCC; thus it seems relevant first to consider to what extent the authors (40 in all) are present, as a collective voice. Unsurprisingly, there are no occurrences of the first person plural pronoun we - not a single direct reference to the collective voice of the forty authors. This absence indicates that the text is related to the norms of scientific discourse (Fløttum et al. 2006). However, for the text analysed here, the context in which it is produced makes it reasonable to assume that it will display a mix of scientific and political traits. In fact, even though the pronoun we is not present, the voices of the authors are present throughout the text; person manifestation may be mapped by other devices (such as adverbs, connectives, modal verbs, pronouns).

In examples (1) - (4) we observe that the authors comment on underlying voices by means of scientifically defined expressions. In addition, the text contains a high number of epistemic modifiers such as modal verbs like may (13 occurrences), might (1), could (11) and would (17). These verbs may convey quite different semantic content, but also the epistemic value of toning down the propositional content of the sentence in which they occur, marking some kind of hesitation. In the present context, this may be considered as an example of polyphony, where the authors add their point of view as a comment to the un-nuanced and underlying point of view, which may exist within the 
actual scientific community. Thus we have an internal discussion, with expressed uncertainty. Here is an example containing the modal verb may, where an underlying point of view - "it is difficult..." - is modified by a modal point of view "it may be difficult ...":

(7) Without substantial investment flows and effective technology transfer, it may

be difficult to achieve emission reduction at a significant scale. (p. 20)

17 I will now focus on one specific linguistic device indicating the presence and mixing of voices in the construction of concession, limiting my illustration to one marker of this kind of implicit polyphony, i.e., the contrastive connective but (in its concessive use). This selection is justified by the very frequent use of this specific marker (in addition to the marker of negation, which I will not comment here) in both political (Fløttum \& Stenvoll 2009) and scientific discourse (Fløttum et al. 2006) in general, and in the current text in particular.

18 The theoretical framework of the analysis is ScaPoLine, a theory of linguistic polyphony (Nølke et al. 2004; ScaPoLine is short for la théorie scandinave de polyphonie linguistique). In a very simplistic way, we may say that this approach is based on a conception of language as fundamentally dialogic, presenting itself as an alternative to the established idea of the uniqueness of the speaking subject (inspired by sources as different as Bakhtine 1984 and Ducrot 1984). The main idea is that in one single utterance there may be several voices or points of view present, in addition to the one of the speaker/writer. The ScaPoLine theory may be used to clarify complex multivoiced sequences with both explicit presence of different points of view (as in citations and different kinds of reported speech) and implicit presence (signalled by various markers).

19 We will see how the theory can be exemplified through an excerpt (8) of concession containing the polyphonic marker but in its contrastive and concessive capacity:

(8) Such changes [in metres of sea level rise] are projected to occur over millennial time scales, but more rapid sea level rise on century time scales cannot be excluded. (p. 13)

First, a construction with but can be formalised as $p$ but $q$ where $p$ and $q$ constitute two propositions - or arguments - in contrast: $p$ represents the concession and $q$ the argument that the speaker identifies him- or herself with. In the polyphonic analysis these are treated as points of view (pov), and example (8) can be linguistically analysed as follows, in four povs:

pov1: such changes are projected to occur over millennial time scales

pov2: pov1 is an argument in favour of the conclusion $r$

pov3: more rapid sea level rise on century time scales cannot be excluded

pov4: pov3 is an argument in favour of the conclusion non-r.

The letter $r$ symbolises a conclusion which is to be searched for in the interpretation phase of the analysis, i.e., in the context. In everyday language, the interpretation of example (8) could be translated as follows: The speaker accepts that "such changes are projected to occur over millennial time scales". Implicitly this pov also orients the discourse towards a conclusion $(r)$ that there is "no reason to worry now". However, by the connective but, it is emphasised that what counts here and now is that "more rapid sea level rise on century time scales cannot be excluded", with an implicit conclusion (non-r) saying "Do worry!". A further interpretation would have to consider who the responsible sources of the expressed points of view are. Given the context of the IPCC work, this but-construction could be interpreted as a reflection of an internal 
polyphonic exchange of pov. There are different voices because of different research results and because of different kinds of uncertainties. The first pov has as its source some specific results and the second other results. It is nevertheless important to note that what matters here and now for the speaking voice is the proposition introduced by but.

This example contains in addition another signal of polyphony - the negation not in "more rapid sea level rise on century time scales cannot be excluded". We know from many public debates that sea level rise is a "hot" topic. In (8), the IPCC official voice refutes that more rapid sea level rise can be excluded. This indicates that some researchers may have postulated that it can be excluded.

Here is another example with the concessive but, also including the modal verbs can and may, adding a hesitating or uncertain point of view to the claim and thus showing the epistemic complexity and the underlying discussion this kind of discourse represents:

(9) Making development more sustainable can enhance mitigative and adaptive capacities, reduce emissions and reduce vulnerability, but there may be barriers to implementation. (p. 18)

These few examples have shown how the polyphonic perspective may help to detect subtle interactions contributing to the negotiation of different relations, represented by different voices. A further direct relevance for the present analysis is that the identification of such markers and voices can make the analyst sensitive to relevant contextual factors and thus be a good starting point for a broader socio-political analysis of the text. However, even though we observe these traces of different voices, we may sum up the analyses undertaken in 2.1 and 2.2 as indicating an orientation towards consensus. There are no traces of explicit polemic, only "mild" concessions. We meet a negotiated collective official IPCC voice in the Summary.

\section{Narratives ("stories") in reports about Climate Change}

\subsection{Introduction}

This section will assume a textual and discursive perspective, with a special focus on the relevance of the notion of narrative. Climate change text and talk come in many varieties and genres, through different channels and voices: scientific reports and research papers, news media articles, political manifestos and speeches, NGO programmes, White Papers, blogs, social media discussions and individual personal stories - with multiple actors involved. How do these actors, from different institutional contexts, construct linguistically and discursively their climate policy? My point of departure is the hypothesis that a narrative analysis may be a fruitful perspective for the understanding of climate change discourse (see also Jones \& McBeth 2010).

26 I will first discuss the notion of narrative, in order to proceed to an analysis in this perspective, where I will rely on examples from the two following texts: 
Unsurprisingly, preliminary studies of various documents related to climate change clearly indicate that there is not one discursive genre in which we can put these documents (see Fløttum 2013; Fløttum \& Dahl 2012; Fløttum \& Gjerstad 2013a, b). As mentioned above, they come in many varieties and genres, and often represent hybrids of scientific, political and other voices where different genres are mixed. However, the claim I make here is that these documents can be considered to be part of what could be called climate change narratives. By "climate change narrative" I refer to text and talk that present climate change as a certain type of problem/complication, with implicit or explicit recommendations or imperatives for action(s) which take place or should take place to achieve some particular effect(s) (or final situation) - that is, narratives have a plot. In addition, different characters or actors are involved, such as nature, humans, society, countries, assuming the roles of hero, victim or villain. Ethical perspectives may also be included.

31 There are many kinds of narratives, and the notion has often been used in a rather noncritical way. Here I return to the classical structure of a narrative (studied mostly in literary or fiction contexts), which has been discussed since ancient times. However, different approaches tend to agree that there are five main components (see for example Adam 1999, 2008). I will not go further into a discussion of the narrative structure here, but just give an illustration through a made-up but nevertheless realistic example:

(10)

1. Initial situation: Human beings lived in harmony with nature.

2. Complication: $\mathrm{CO}_{2}$ emissions have increased dramatically since 1990 and have caused serious climate change.

3. Re-action: The UN organises international summits (COPs) to discuss action on climate change.

4. Outcome (Resolution): But the negotiating countries have not reached any binding agreement of measures to undertake.

5. Final situation: Climate change constitutes a serious threat to the Planet and future generations, and those who have contributed least to the problems are the ones most vulnerable to the consequences. 


\subsection{Analysis of climate change international and national documents}

The two documents mentioned above - the HDR and WDR texts - deal with climate change, provide situational descriptions and offer policy advice. The starting point for both documents is the recognition that those who have contributed least to climate change are the ones who are most vulnerable to the consequences, which may be interpreted as both the initial situation of a narrative and a moral component. There are no clear heroes, but in a very general way we may say that the rich countries are presented as the villains and the poor countries as the victims:

(11) Rich nations and their citizens account for the overwhelming bulk of the greenhouse gases locked in the Earth's atmosphere. But, poor countries and their citizens will pay the highest price for climate change. (HDR: 3 )

(12) High-income countries can and must reduce their carbon footprints. (WDR: 1)

However, given the contextual and institutional framing of the reports, which I cannot go into here (see Gasper et al. 2013), we may hypothesise that the "stories" they present diverge in some respects. In fact, both texts focus on the causes of climate change in their initial situation description, but differ in how the rest of the schema is developed: While HDR seems to focus mainly on the complication and evaluation components, WDR has its main focus on the (re-)action component. This difference may be explained by different interpretations of the facts presented, according to different institutional contexts, which thus results in somewhat different "stories".

For HDR, in the narrative perspective, the battle against climate change is part of the fight for humanity; climate change threatens human freedom. The main focus of the report thus seems to be moral responsibility. The world's poor and future generations are directly addressed:

(13) In today's world, it is the poor who are bearing the brunt of climate change. Tomorrow, it will be humanity as a whole that faces the risks that come with global warming. [...] The battle against dangerous climate change is part of the fight for humanity. (HDR: 2, 6)

In contrast to the HDR Overview, and in the narrative perspective, the WDR Overview focuses more on the (re-)action dimension than on the complication. It seems reasonable to interpret the main message of this report as the necessity to promote growth in order to reduce poverty (27 occurrences of the word growth):

(14) Economic growth is necessary to reduce poverty and is at the heart of increasing resilience to climate change in poor countries. (WDR: 7)

Climate change is almost blamed (is it the villain?) because it may hinder growth. The report urges the world to be "climatesmart" and to find solutions without affecting our ways of life too much. The WDR also demonstrates a firm belief in technology, ingenuity, and innovation.

Finally, I would like to comment on a couple of other documents I have analysed in collaboration with colleagues within the LINGCLIM project (see section 4). First, the White Paper on "climate change response" published by the Government of the Republic of South Africa (for details, see Fløttum \& Gjerstad 2013b). This political document also has a story to tell. The narrative analysis revealed a complex plot, where South Africa is portrayed as both villain and victim. The government acknowledges South Africa's responsibilities regarding substantial greenhouse gas emissions, but 
emphasises that the country is expected to suffer dramatically from the adverse effects of projected climate change, and points to the poor as particularly vulnerable in this respect. However, the government attributes the clearest role to itself. Both internationally and domestically it constructs itself as the hero of its own narrative, which should not come as a surprise in this kind of political document. Governments are of course heroes of their own white papers - a trait which is important to the understanding of these documents.

Our research team is currently working on two Norwegian White papers, one on the country's climate policy (Norsk klimapolitikk, Meld. St. 21, 2011-2012) and the other one on the policy of the High North (the Arctic; Nordområdene, Meld. St. 7, 2011-2012). Through a narrative analysis we there investigate a hypothesis on Norway's duality in its climate change policy. There seems to be two stories, one about Norway wanting to be leading in global climate and environmental questions and the other about Norway's oil resources and the so-called necessity to extract more oil and gas in order to help the poor in other parts of the world, those who have not access to energy. This duality represents all in all an ambiguous message to the Norwegian public. It remains to study to what extent this ambiguity leads to the indifference and lack of engagement currently observed in the climate question.

\section{Final remarks - towards interdisciplinarity}

The textual-discursive analysis undertaken in section 3 has shown that the notion of narrative may be a useful frame for comparative studies and thus to better understand the climate change debate at both a national and a global level. However, the narrative is only a frame. To understand what is really said, we have to move from the macro- to the micro-level, and undertake in-depth studies of linguistic features. There are many features which are obviously relevant to climate discourse: expressions of epistemic, deontic and axiological modality, adverbial expressions (or different types of hedging), connectives, pronouns, lexical choices, metaphors, reported speech. I mentioned some of these in the analysis of the IPCC summary (section 2), to a large extent realised through a polyphonic or multi-voiced perspective. Multiple voices are introduced in the climate change debate, at a macro-level by the different institutions, actors and stakeholders, but also at a micro-level by different voices within the particular narratives. There is explicit or implicit inclusion of many and different viewpoints (Fløttum 2010; Fløttum \& Dahl 2011; Fløttum \& Gjerstad 2013a, b). This represents a specific dilemma for the IPCC, which is expected to reflect differing viewpoints and at the same time present one consensual view. In general, for all CCNs, central questions are which voices are present and which ones are dominating. For example, in the narratives briefly interpreted here, there are large differences as regards the presence of explicit and implicit voices. This perspective is particularly important for the question who says what.

To conclude, the use of language in climate change discourse is hotly debated, and more research is needed. The heterogeneity we observe and the mix of voices from different fields and sectors may also call for new approaches. For a fuller understanding of the construction, the interpretation and the circulation of climate knowledge and claims, linguistic and discursive studies should be undertaken in collaboration with both social and natural sciences in truly integrated and 
interdisciplinary approaches. It is a matter of studying how language may represent an extremely complex reality but also, and importantly, how language is interpreted and contributes to the construction of this reality.

More cross-disciplinary collaboration is thus needed:

In order to better understand the relationship between science-based knowledge and what is actually said or written in the public or private sphere, linguists and climate scientists should collaborate.

In order to better understand the relationship between language representations and people's interpretations and response, linguists and psychological scientists should collaborate.

4 In order to better explain public opinion, in terms of patterns of consensus and controversy (among different kinds of actors and voices), linguists and political social scientists should collaborate.

5 To meet these requirements, we have, at the University of Bergen, started a new interdisciplinary relatively large three-year project: the LINGCLIM project, short for LINGuistic representations of CLIMate change discourse and their individual and collective interpretations (<www.uib.no/en/project/lingclim>). The core group of the project consists of researchers from linguistics, psychological, political, climate and computational sciences.

Our point of departure has always been that the meaning people ascribe to climate change is closely related to how the phenomenon is portrayed, and thus the importance of language. Our main objective is to generate integrated knowledge about the role of language in climate change discourse through developing a multidisciplinary methodology and to unveil the relationship between linguistic representations and collective and individual interpretations. These considerations are based on the hypothesis that language influences which knowledge structures and connotations are activated and which inferences are drawn by people. In order to achieve our aim we have a four-tier methodology, where the main components are:

Linguistic and discursive analyses related to the representations of climate change knowledge and discourse.

An opinion survey (through the Norwegian Citizen Panel), which will help us to understand more about the collective interpretations.

With the results of the opinion survey, we will elaborate psychological experiments, from which we will learn more about individual interpretations of climate change discourse.

50 And finally, since we are interested in knowing more about the voices of young people, their attitudes and opinions, we interact with high-school students and teachers.

Even though very complex and challenging, this way of integrating language studies will, in our view, contribute to an improved and much needed knowledge base of issues related to climate change. We hope it will help to meet the challenge related to the fact that, while science is making great progress, the use of science in policy-making - as well as the interaction between science and the general public - is lagging behind. Linguistic and discursive studies can contribute in a very decisive way towards this aim. 


\section{BIBLIOGRAPHIE}

Adam, Jean-Michel. 1999. Linguistique textuelle. Des genres de discours aux textes. Paris: Nathan. Adam, Jean-Michel. 2008. La linguistique textuelle. Introduction à l'analyse textuelle des discours. Paris: Armand Colin.

Bakhtine, Mikhail. 1984 [1952]. "Les genres du discours”. In Bakhtine, M. Esthétique de la création verbale. Paris: Gallimard, 265-308.

Budescu, David V., Stephen Broomell \& Han-Hui Por. 2009. "Improving communication of uncertainty in the reports of the Intergovernmental Panel on Climate Change." Psychological Science 20/3, 299-308.

Ducrot, Oswald. 1984. Le Dire et le Dit. Paris: Minuit.

Fløttum, Kjersti. 2010. “A linguistic and discursive view on climate change discourse”. ASp 58, 1937.

Fløttum, Kjersti. 2013. "Narratives in reports about climate change". In Gotti, M. \& C.S. Guinda (eds), Narratives in Academic and Professional Genres. Bern: Peter Lang, 277-292.

Fløttum, Kjersti \& Trine Dahl. 2011. “Climate change discourse: Scientific claims in a policy setting”. Fachsprache 3-4, 205-219.

Fløttum, Kjersti \& Trine Dahl. 2012. "Different contexts, different 'stories'? A linguistic comparison of two development reports on climate change". Language \& Communication 32/1, 1423.

Fløttum, Kjersti, Trine Dahl \& Torodd Kinn. 2006. Academic Voices across Languages and Disciplines. Amsterdam: Benjamins.

Fløttum, Kjersti \& Øyvind Gjerstad. 2013a. "Arguing for climate policy through the linguistic construction of narratives and voices: The case of the South-African green paper 'National Climate Change Response". Climatic Change 118/2, 417-430 DOI: 10.1007/s10584-012-0654-7.

Fløttum, Kjersti \& Øyvind Gjerstad. 2013b. “The role of social justice and poverty in South Africa's national climate change response white paper". South African Journal on Human Rights 2013-1, 6190.

Fløttum, Kjersti \& Dag Stenvoll. 2009. "Blair speeches in a polyphonic perspective. NOTs and BUTs in visions on Europe". Journal of Language and Politics 8/2: 269-286.

Gasper, Des, Anna V. Porto Carrero \& Asuncion L. St.Clair. 2013. “Climate change and development framings: A comparative analysis of the human development Report 2007/8 and the World Development Report 2010". Global Environmental Change 23/1, 28-39.

Giddens, Anthony. 2009. The Politics of Climate Change. Cambridge, UK/Malden, MA, US: Polity Press.

Hulme, Mike. 2009. Why We Disagree About Climate Change. Cambridge: Cambridge University Press. Hulme, Mike. 2013. Exploring Climate Change through Science and in Society. London: Palgrave. Jones, Michael \& Mark K. McBeth. 2010. “A narrative policy framework: Clear enough to be wrong?”. Policy Studies Journal 38/2, 329-353.

Leiss, William. 2004. "Effective risk communication”. Toxicology Letters 149, 399-404. 
Leiserowitz, Anthony. 2007. "Communicating the risks of global warming: American risk perceptions, affective images and interpretive communities". In Moser, S. \& L. Dilling (eds.), Creating a Climate for Change. Cambridge: Cambridge University Press, 44-63.

Malone, Elisabeth L. 2009. Debating Climate Change. London: EarthScan.

Nerlich, Brigitte, Nelya Koteyko \& Brian Brown. 2010. "Theory and language of climate change communication". Wiley Interdisciplinary Reviews: Climate Change 1/1, 97-110.

Nølke, Henning, Kjersti Fløttum \& Coco Norén. 2004. ScaPoLine. La théorie scandinave de la polyphonie linguistique. Paris: Kimé.

Patt, Anthony \& Daniel Schrag. 2003. "Using specific language to describe risk and probability". Climatic Change 61, 17-30.

Weingart, Peter, Anita Engels \& Petra Pansegrau. 2000. "Risks of communication: Discourses on climate change in science, politics, and the mass media". Public Understanding of Science 9 , 261-283.

Zaccai, Edwin, François Gemenne \& Jean-Michel Decroly. 2012. Controverses climatiques, sciences et politique. Paris: Presses de Sciences Politiques.

\section{NOTES}

1. There is a new full report to be published with its different parts in 2014 (probably September; the first part related to the status of the natural sciences in the issue is already published); it will be interesting to analyse the summary of the new report when it is ready - in comparison with the one analysed here.

\section{RÉSUMÉS}

Depuis plusieurs années, les sciences de la vie et de la terre ont identifié les causes et effets du changement climatique, mettant en évidence la complexité de ce phénomène et les incertitudes qui lui sont associées. Ce défi global est un des problèmes les plus sérieux de l'humanité. Cependant, le débat actuel révèle des divergences entre les résultats présentés par les sciences du climat et les « histoires » circulant dans les médias, chez les politiciens et dans le grand public. Dans cette situation, le langage joue un rôle fondamental. Dans le présent article, des faits linguistiques et discursifs utilisés dans le discours portant sur le changement climatique sont discutés. La problématique est abordée en premier à travers diverses représentations linguistiques, notamment des expressions d'incertitude, repérées dans les documents de l'IPCC (Intergovernmental Panel on Climate Change ; GIEC en français). Ensuite, une perspective plus discursive est explorée, dans une argumentation soutenant que la notion de "narrativisation » pourra contribuer à une meilleure compréhension des multiples «histoires " qui sont construites. Dans cette partie, les analyses sont principalement fondées sur des documents produits dans la sphère politique. 
For several decades, the natural sciences have documented causes and effects of climate change, with all its complexity and inherent uncertainty. This global challenge is one of the most pressing issues facing humanity today. However, the current debate reveals some discrepancies between the claims and evidence presented by climate sciences and the "stories" circulating in the media, among politicians and ordinary citizens. In this, language plays a crucial role. In this article, different linguistic and discursive features frequently used in climate change discourse will be discussed. First, the issue will be approached through various linguistic representations, in particular expressions of uncertainty, taken from documents by the IPCC (Intergovernmental Panel on Climate Change). Second, a more discursive perspective will be adopted, arguing that the notion of narrative may contribute to a better understanding of the multiple "stories" which are constructed about the issue. In this part, the analyses will mainly be based on materials of political nature.

\section{INDEX}

Keywords : discourse analysis, interdisciplinarity, narrative, polyphony, uncertainty Mots-clés : analyse du discours, incertitude, interdisciplinarité, narration, polyphonie

\section{AUTEUR}

\section{KJERSTI FLØTTUM}

Kjersti Fløttum is Professor of French linguistics at the Department of Foreign Languages, University of Bergen, where she teaches text theory and discourse analysis. She headed the Bergen Summer Research School (BSRS) on Global Development Challenges 2008-2011. Her general research fields are related to text and genre theory with a special focus on linguistic polyphony and dialogism in scientific, political and climate change discourse. She is head of the multidisciplinary project LINGCLIM: Linguistic representations of climate change discourse and their individual and collective interpretations (2013-2015), investigating the role of language in the climate change debate, on national and international levels. K. Fløttum is co-author of Academic Voices (2006), editor of Speaking to Europe (2013) and has published extensively in international journals including Journal of Pragmatics, Journal of Language and Politics, Language \& Communication and Climatic Change. kjersti.flottum@if.uib.no 